\title{
Prediction of daily milk production from the linear body and udder morphometry in Holstein Friesian dairy cows
}

\author{
Soeharsono Soeharsono ${ }^{1}$, Sri Mulyati ${ }^{2}$, Suzanita Utama ${ }^{2}$, Wurlina Wurlina², Pudji Srianto², Tjuk Imam Restiadi ${ }^{2}$ and \\ Imam Mustofa² (iD)
}

1. Department of Veterinary Anatomy, Faculty of Veterinary Medicine, Universitas Airlangga, Kampus C Unair, JI. Mulyorejo, Surabaya-60115, Indonesia; 2. Department of Veterinary Reproduction, Faculty of Veterinary Medicine, Universitas Airlangga, Kampus C Unair, Jl. Mulyorejo, Surabaya-60115, Indonesia.

Corresponding author: Imam Mustofa, e-mail: imam.mustofa@fkh.unair.ac.id

Co-authors: SS: soeharsono@fkh.unair.ac.id, SM: srimulyati_s3unair@yahoo.co.id, SU: suzanitautama@hotmail.com, WW: wurlina_made@yahoo.co.id,PS: pudjisrianto@yahoo.com,TIR: tjukir@yahoo.com

Received: 29-10-2019, Accepted: 10-02-2020, Published online: 13-03-2020

doi: www.doi.org/10.14202/vetworld.2020.471-477 How to cite this article: Soeharsono S, Mulyati S, Utama S, Wurlina W, Srianto P, Restiadi TI, Mustofa I (2020) Prediction of daily milk production from the linear body and udder morphometry in Holstein Friesian dairy cows, Veterinary World, 13(3): 471-477.

\begin{abstract}
Aim: This study aimed to develop equations to predict daily milk production (DMP) based on linear body and udder morphometry of Holstein Friesian (HF) dairy cows.

Materials and Methods: The experiment was conducted on 174 lactating HF dairy cows reared by farmers at different locations under similar conditions. The age, parity, and body condition score of experimental animals were limited to 0.25 of the standard deviation value above or below the average. The average DMP was based on farmers' records. Morphometry components, i.e., body length (BL); chest circumference (CC); front udder height (FUH), rear udder height (RUH); and udder circumference (UC) were directly measured using a tape; meanwhile, body weight (BW) was estimated using the Indonesia Winter formula. The relationship variables of morphometry components (body and udder morphometry) and BW on DMP were analyzed by regression.
\end{abstract}

Results: The result showed no correlation $(\mathrm{p}>0.05)$ between CC and BW on DMP. Meanwhile, DMP obtained linear regression $(\mathrm{p}<0.05)$ with the mathematical equation: $1.30+0.11 * \mathrm{BL} ; 13.90+0.41 * \mathrm{FUH} ; 11.02+0.18 * \mathrm{RUH}$; and $3.87+0.16 * \mathrm{UC}$.

Conclusion: This study shows that the DMP of dairy cows could be predicted based on their BL and udder morphometry.

Keywords: body length, front udder height, milk production, rear udder height, udder circumference.

\section{Introduction}

Holstein Friesian (HF) cows have been reared in Indonesia since the $18^{\text {th }}$ century. The cows have to adapt to highlands of up to $700 \mathrm{~m}$ and lowlands that are 0-100 $\mathrm{m}$ above sea level with temperatures and humidity of $16-23^{\circ} \mathrm{C}$ and $92 \%$ or $28-35^{\circ} \mathrm{C}$ and $54 \%$, respectively [1]. The weather influences feed intake and the efficiency of milk production. Over the centuries, this has led to physiological and morphological adaptations. Under high ambient temperatures, livestock reduces dry matter intake to decrease their metabolic heat production; meanwhile, for high-yielding dairy cows, a high intake of dry matter is needed [2]. The difference in body weight (BW) is, of course, followed by changes in body morphometry and milk production. The average BW of a cow reared in sub-tropical areas is higher than that of a cow reared in tropical areas, which affects average milk production [3]. Milk is synthesized in the milk-producing unit called alveoli in the mammary

Copyright: Soeharsono, et al. Open Access. This article is distributed under the terms of the Creative Commons Attribution 4.0 International License (http://creativecommons.org/licenses/ by/4.0/), which permits unrestricted use, distribution, and reproduction in any medium, provided you give appropriate credit to the original author(s) and the source, provide a link to the Creative Commons license, and indicate if changes were made. The Creative Commons Public Domain Dedication waiver (http:// creativecommons.org/publicdomain/zero/1.0/) applies to the data made available in this article, unless otherwise stated. gland. The capacity for milk synthesis depends on the number and efficiency of functional mammary epithelial cells. It is affected by protein intake [4], hypothetically influenced by body and udder morphometry.

The problem faced by smallholder farmers is having limited facilities to find out the BW and production records of cows. Farmers choose a dairy cow based only on the visual estimation of body and udder sizes without any quantitative measurements. This method is certainly far from accurate to get dairy cows with high milk production. For this reason, there is a necessity for a simple measurement method that is cheap and can be done by everyone as a guideline for estimating a productive dairy cow. The principle of the estimation method is to transform a known variable to be the desired variable value. The relationship of the body size to other parameters can be modeled in the regression equation [5]. BWs can be predicted through body morphometry based on body length (BL) and chest circumference (CC) [6] using the Indonesia Winter formula. Measurements using the estimation method, although not more accurate than direct measurements, have significant uses in terms of practicality, especially at the level of the smallholder farmers.This study aimed to develop equations to predict daily milk production (DMP) based on linear body and udder morphometry of HF dairy cows. 


\section{Materials and Methods}

\section{Ethical approval}

This research was conducted under the supervision of an assessor of the Animal Care and Use Committee (ACUC) from the Faculty of Veterinary Medicine, Universitas Airlangga, Surabaya, Indonesia.

\section{The location of the study and study period}

This study was conducted in Jambuwer Village, Wagir District, Malang Regency, Indonesia during eight months (September 2018 - April 2019). The geographic location and the data of the weather were obtained from the global positioning system [7] and Meteorological, Climatological, and Geophysical Agency [8], respectively. Wagir District is located $\pm 450 \mathrm{~m}$ above the sea level (ASL) at the slopes of Mount Kawi, with temperatures ranging from 11 to $25^{\circ} \mathrm{C}$, with an average humidity of $79 \%-86 \%$. Geographically, it was located at $112^{\circ} 17^{\prime} 10^{\prime \prime}$ $112^{\circ} 57^{\prime} 00^{\prime}$ " east longitude (EL) and 7०44'55.11'"$8^{\circ} 26^{\prime} 35.45^{\prime \prime}$ south latitude (SL). Jambuwer Village was in the Wagir District, on 433 ASL, geographically located at $112^{\circ} 31^{\prime} 3^{\prime \prime}$ EL and $8^{\circ} 1^{\prime} 31^{\prime \prime} \mathrm{SL}$, with temperature ranges from 18 to $28^{\circ} \mathrm{C}$ and average humidity of $86 \%$.

The mathematical equation of linear regression was then cross-checked on cows at two different locations. The first was Precet Village, Wagir District, located $474 \mathrm{~m} \mathrm{ASL}$, at $112^{\circ} 30^{\prime} 36^{\prime \prime} \mathrm{EL}$ and $8^{\circ} 0^{\prime} 8^{\prime}$ " SL, with an ambient temperature of $18-28^{\circ} \mathrm{C}$ and average humidity of $74 \%$. The second was Geger Village, Sendang District, located $652 \mathrm{~m} \mathrm{ASL}$, at 111 50 '0" EL, and $7^{\circ} 57^{\prime} 0^{\prime}$ ' SL, with an ambient temperature of $18-27^{\circ} \mathrm{C}$ and average humidity of $88 \%$.

\section{Experimental animals}

This study used HF cows owned by smallholder farmers. The cows were healthy and lactating. The age, parity, and body condition score (BCS) of experimental animals were limited to 0.25 of the standard deviation value above or below the average. The HF cows were aged 4-8 years, had a parity of $2-5$, and BCS of 4-6 on a nine-point scale. The cows were randomly selected from the population based on these criteria.

\section{Management of animals}

The cows were cowshed all day long and managed traditionally. Milking was conducted twice a day, in the morning, at 03.00-06.00, and in the afternoon, at 13.00-15.00. In the early morning, the farmers prepared for milking by cleaning the pen, feeding the cows concentrate, and washing them. Milking was conducted by hand, one cow at a time. The milk yield of each cow was measured, and the milk collected in the milk can then delivered to the milk collecting point of the cooperative. In about $1 \mathrm{~h}$ after milking, the cows were fed grass.

Dairy cows were fed $25-35 \mathrm{~kg}$ of elephant grass and $9-16 \mathrm{~kg}$ of concentrate daily, while water was available ad libitum. In the morning, the feed given was as much as $40 \%$, while in the afternoon, it was $60 \%$. The farmers obtained elephant grass from fields around the cowshed for a 1-day stock only. Meanwhile, a concentrate containing 16-18\% rough protein was supplied by the cooperative.

\section{Recording of parameters}

The measurements of body morphometry, i.e., $\mathrm{BL}$ and $\mathrm{CC}$, and udder morphometry, i.e., front udder height (FUH), rear udder height (RUH), and udder circumference (UC), were carried out using a measuring tape scale of $200 \mathrm{~cm}$. The BL was measured from the manubrium of the sternum to the tip of the tuber ischia, while the value of the $\mathrm{CC}$ was obtained by looping the measuring tape on the body of the cow behind the scapula. The parameter measurements of each cow were obtained twice a day before milking for three replications at 7-day intervals. Based on the BL $(\mathrm{cm})$ and $\mathrm{CC}(\mathrm{cm})$ of each cow, the BW $(\mathrm{kg})$ of the cow could be calculated based on the Winter Indonesia formula: $\left.\mathrm{BW}=(\mathrm{CC})^{2} \times \mathrm{BL}\right) / 10,815.15$ [9]. The FUH was measured perpendicularly from the point of attachment in the ventral abdomen to the lowest point of the front udder; RUH was straight upright from the highest mammary point at the cow's caudal body to the lowest point of the rear udder, and UC was measured based on the largest UC between the two hind legs of the cow. The DMP was the average daily milk yield of the last lactation period collected from the farmer record.

\section{Statistical analysis}

All the variables were analyzed to find out the normality of the distribution using the Kolmogorov-Smirnov test, followed by the correlation of one to each other. When the correlation among variables was significant, the study would continue to find the linear regression to the average DMP (1/day). A linear regression line has the equation: $\mathrm{Y}=\mathrm{a}+\mathrm{bX}$, where " $\mathrm{X}$ " is the explanatory or the independent variable, and "Y" is the dependent one. The slope or the beta coefficient of the line is "b", while "a" is the intercept (the value of $y$ when $x=0$ ). The value of coefficient correlation (r) and its meaning, i.e., 0.000.19 is very weak; $0.20-0.39$ is weak, $0.40-0.59$ is moderate, $0.60-0.79$ is strong, and $0.80-1.0$ is very strong [10]. If regression is met, the trailing checks of goodness of fit include the R-squared and hypothesis testing of individual parameters by t-tests. The coefficient of determination, $\mathrm{R}^{2}$, represents the proportion (\%) of the variance for a dependent variable that is explained by an independent variable [11]. The computed equation of linear regression cross-checked the suitability between the predicted DMP (e-DMP) then compared it to real DMP (r-DMP) in other locations of smallholder dairy farmers. Statistical analysis was conducted at a 95\% level of significance.

\section{Results}

Based on the criteria mentioned earlier, 174 cattle were obtained that meet the requirements. Homogeneity 
examination using a Kolmogorov-Smirnov test of all the parameters showed that the data were normally distributed $(\mathrm{p}>0.05)$. The average age, parity, and BCS of the cows were $4.87 \pm 1.13$ years, $2.23 \pm 0.12$, and $5.14 \pm 0.15$, respectively. The daily average of cows feeding was $33.91 \pm 0.73 \mathrm{~kg}$ elephant grass and $10.44 \pm 0.64 \mathrm{~kg}$ concentrate $(22.77 \pm 1.17 \%$ of feed); meanwhile, the average DMP was $17.66 \pm 3.47 \mathrm{l} / \mathrm{d}$. The average body morphometry: BL was $\mathrm{C} 166.68 \pm 7.28$ $\mathrm{cm}, \mathrm{CC}$ was $188.79 \pm 8.46 \mathrm{~cm}$, and $\mathrm{BW}$ was $550.57 \pm 60.98 \mathrm{~kg}$. Furthermore, the udder morphometry: FUH was $9.16 \pm 1.16 \mathrm{~cm}$, RUH was $37.81 \pm 7.76 \mathrm{~cm}$, and UC was $87.86 \pm 15.33 \mathrm{~cm}$ (Table-1).

\section{Correlation among variables}

There was significant correlation $(\mathrm{p}<0.05)$ between BL with CC, BW, FUH, RUH, and DMP; CC with $\mathrm{BL}$ and $\mathrm{BW}$; $\mathrm{BW}$ with $\mathrm{BL}$ and $\mathrm{CC}$; FUH with $\mathrm{BL}$, RUH, UC, and DMP; RUH with BL, BW, FUH, UC, and DMP; UC with FUH, RUH, and DMP; and DMP with BL, FUH, RUH, and UC (Tables-2 and 3).

\section{The effect of morphometry on DMP}

In this study, the e-DMP was based on the body components that were $\mathrm{BL}, \mathrm{CC}, \mathrm{BW}, \mathrm{FUH}$, RUH, and UC. Four of them were significant correlations $(p<0.05)$ to DMP, i.e., BL, FUH, RUH, and UC (Tables-2 and 3). Mathematical equation and regression graph of the relationship of body components to DMP are presented in Table-4 and Figure-1, respectively.

Based on the mathematical equation, Table-4 shows the e-DMP compared to actual DMP (r-DMP) in dairy cows in this study and of other locations (Table-5). The result showed that FUH and UC at location II were lower $(p<0.05)$ compared to the other locations, followed by lower r-DMP, e-DMP-FUH, and e-DMP-UC. In contrast, the other predictors (BL

Table-1: Age, parity, BCS, nutrient intake, daily milk production, estimated body weight based on the Winter formula, body length, chest circumference, front udder height, rear udder height, and udder circumference of Friesian Holstein dairy cows $(n=174)$.

\begin{tabular}{|c|c|c|c|c|}
\hline Variables & Minimum & Maximum & Mean & Standard deviation \\
\hline Age (years) & 4 & 8 & 4.87 & 1.13 \\
\hline Parity & 2 & 5 & 2.23 & 0.12 \\
\hline Body condition score (BCS, nine scales) & 4 & 6 & 5.14 & 0.15 \\
\hline \multicolumn{5}{|l|}{ Nutrient intake: } \\
\hline Forage (kg) & 25 & 35 & 33.91 & 0.73 \\
\hline Concentrate (kg) & 9 & 16 & 10.44 & 0.64 \\
\hline \% Concentrate & 16.57 & 31.38 & 22.77 & 1.17 \\
\hline Daily milk production (DMP, I/day) & 7 & 37 & 17.66 & 3.47 \\
\hline Body length (BL, cm) & 153 & 179 & 166.68 & 7.28 \\
\hline Chest circumference (CC, cm) & 168 & 214 & 188.79 & 8.46 \\
\hline Estimation of bodyweight (BW, kg) & 411.38 & 743.55 & 550.57 & 60.98 \\
\hline Front udder height (FUH, cm) & 7 & 17 & 9.16 & 1.16 \\
\hline Rear udder height (RUH, cm) & 18 & 56 & 37.81 & 7.76 \\
\hline Udder circumference (UC, cm) & 51 & 160 & 87.86 & 15.33 \\
\hline
\end{tabular}

Table-2: Pearson matrix correlation among variables.

\begin{tabular}{|c|c|c|c|c|c|c|c|}
\hline Variables & BL & CC & BW & FUH & RUH & UC & DMP \\
\hline$B L$ & 1 & 0.2999 & 0.6364 & 0.2124 & 0.2202 & 0.0855 & 0.1520 \\
\hline $\mathrm{CC}$ & 0.2999 & 1 & 0.9251 & 0.0771 & 0.1332 & 0.0202 & 0.0596 \\
\hline BW & 0.6364 & 0.9251 & 1 & 0.1451 & 0.1886 & 0.0511 & 0.1109 \\
\hline FUH & 0.2124 & 0.0771 & 0.1451 & 1 & 0.8611 & 0.3317 & 0.1623 \\
\hline RUH & 0.2202 & 0.1332 & 0.1886 & 0.8611 & 1 & 0.4205 & 0.2481 \\
\hline UC & 0.0855 & 0.0202 & 0.0511 & 0.3317 & 0.4205 & 1 & 0.4370 \\
\hline DMP & 0.1520 & 0.0596 & 0.1109 & 0.1623 & 0.2481 & 0.4370 & 1 \\
\hline
\end{tabular}

Values in bold were different from 0 with a significance level of $<0.05$. DMP=Daily milk production, BL=Body length, $\mathrm{CC}=$ Chest circumference, $\mathrm{BW}=$ Bodyweight, $\mathrm{FUH}=$ Front udder height, $\mathrm{RUH}=$ Rear udder height, UC=Udder circumference

Table-3: Level significance of correlation among variables.

\begin{tabular}{|c|c|c|c|c|c|c|c|}
\hline Variables & BL & CC & BW & FUH & RUH & UC & DMP \\
\hline$B L$ & $\mathbf{0}$ & 0.0001 & 0.0000 & 0.0049 & 0.0485 & 0.2619 & 0.0452 \\
\hline $\mathrm{CC}$ & $<0.0001$ & 0 & $<0.0001$ & 0.3122 & 0.0177 & 0.7911 & 0.4346 \\
\hline BW & $<0.0001$ & $<0.0001$ & 0 & 0.0561 & 0.0356 & 0.5032 & 0.1451 \\
\hline FUH & 0.0049 & 0.3122 & 0.0561 & 0 & 0.7415 & $<0.0001$ & 0.0324 \\
\hline $\mathrm{RUH}$ & 0.0485 & 0.0177 & 0.0356 & 0.7415 & 0 & 0.1768 & 0.0010 \\
\hline UC & 0.2619 & 0.7911 & 0.5032 & $<0.0001$ & 0.1768 & 0 & $<0.0001$ \\
\hline DMP & 0.0452 & 0.4346 & 0.1451 & 0.0324 & 0.0010 & $<0.0001$ & 0 \\
\hline
\end{tabular}

Values in bold were different from 0 with a significance level $<0.05$. DMP=Daily milk production, $B L=B o d y$ length, $\mathrm{CC}=$ Chest circumference, $\mathrm{BW}=$ Bodyweight, $\mathrm{FUH}=$ Front udder height, $\mathrm{RUH}=$ Rear udder height, $\mathrm{UC}=$ Udder circumference 
and RUH) did not differ significantly ( $\mathrm{p}>0.05)$, both r-DMP and e-DMP.

\section{Discussion}

In this study, data on age, parity, BCS, and nutrient intake (Table-1) were statistically proven homogenous so that the DMP variability could be predicted based on body and udder morphometry. Morphometry is a variable of the breed that describes the capacity of the biological processes affecting milk production [12], and a phenotypic trait, which is a genetic expression in response to the environment, including nutrition. This study showed that there are four variables, i.e., BL, FUH, RUH, and UC that affect DMP significantly $(p<0.05)$, so they could be used as estimators of DMP (Tables-2-4).

\section{The effect of body morphometry and BW on DMP}

When the cow reaches 18 months of age, BL will not increase significantly anymore [13]. BL indirectly measures the vertebrae along with the tissue between the vertebrae arranged in a longitudinal line; meanwhile, CC not only measures the circumference of the bones forming the chest cavity but also the tissue attached, especially the muscles and skin. In the estimation of BW, the highest correlation is also determined by CC. Likewise, morphometric measurements to determine the right space amount in the dairy cowshed are also determined by the parameters of the thorax area [14]. In this study, there was no linear correlation between the $\mathrm{BW}$ and $\mathrm{CC}$ of dairy cows, on

Table-4: Linear regression of morphometry of cows on DMP.

\begin{tabular}{lcc}
\hline Equation & p-value & $\mathbf{R}^{\mathbf{2}} \mathbf{( \% )}$ \\
\hline DMP $=-\mathbf{1 . 3 0 + 0 . 1 1} * \mathbf{B L}$ & $\mathbf{0 . 0 4 5}$ & $\mathbf{2 . 3 1}$ \\
$\mathrm{DMP}=10.25+0.04 * \mathrm{CC}$ & 0.428 & 0.36 \\
$\mathrm{DMP}=11.56+0.01 * \mathrm{BW}$ & 0.115 & 1,23 \\
$\mathrm{DMP}=\mathbf{1 3 . 9 0 + 0 . 4 1} *$ FUH & $\mathbf{0 . 0 3 3}$ & $\mathbf{2 . 6 3}$ \\
$\mathrm{DMP}=\mathbf{1 1 . 0 2 + 0 . 1 8}$ RUH & $\mathbf{0 . 0 0 1 0}$ & $\mathbf{6 . 1 6}$ \\
DMP $=\mathbf{3 . 8 7 + 0 . 1 6}$ UC & $<\mathbf{0 . 0 0 0 1}$ & $\mathbf{1 9 . 5 3}$ \\
\hline
\end{tabular}

Values in bold were different from 0 with a significance level $<0.05$. $\mathrm{DMP}=$ Daily milk production, $\mathrm{BL}=\mathrm{Body}$ length, $\mathrm{CC}=$ Chest circumference, $\mathrm{BW}=$ Bodyweight, $\mathrm{FUH}=$ Front udder height, $\mathrm{RUH}=$ Rear udder height, $\mathrm{UC}=$ Udder circumference the one hand, and DMP, on the other hand. This fact is consistent with earlier reports that a decrease in BW is related to a reduction in the ratio of fat to protein; nevertheless, it does not affect milk production $[15,16]$. However, fluctuations in milk production during the lactation period relate to changes in CC [17].

In this study, BL linearly affects DMP, with the correlation coefficient being very weak $(r=0.15)$, and it affects DMP as the determinant coefficient $\left(\mathrm{R}^{2}\right)$ of $2.31 \%$, the remaining $97.69 \%$ is influenced by other factors. The BL of the Ruminantia is correlated to the small intestine length, where a large portion of digestion and absorption of nutrients occurs. Those nutrients, among others, are processed into milk substituent in the mammary gland [18]. This fact explains that milk production will increase or decrease linearly, according to BL. A longer BL, followed by the length of the small intestine, is much more absorbent of nutrients, which could further increase the DMP.

\section{The effect of udder morphometry on DMP}

The endocrine processes of mammogenesis and lactogenesis are genetic variables in milk production. The development of mammary glands occurs in a longterm process that requires reproductive hormones. In this study, the cows were in the lactation period, aged 4-8 years, with parity of $2-5$, which means the morphometry of the udder was relatively stable and would not develop anymore.

Estrogen receptors are found in the mammary gland; therefore, estrogens have a direct impact on tissues. Meanwhile, an indirect effect of estrogens is the stimulation of prolactin (PRL) release from the pituitary and an increase in the number of PRL receptors in the mammary gland. Estrogen is also necessary for lactogenesis and causes the increased secretion of growth factors (insulin-like growth factor [IGF-1], and transforming growth factor- $\alpha$ ) and the increased sensitivity of glandular cells. The critical factor for lactation initiation is an appropriate estrogen to progesterone ratio [19]. Changes in progesterone and PRL at the end of pregnancy lead to an early signal of lactation [20]. In lactating dairy cows, the PRL is

Table-5: Crosscheck of the e-DMP compared to the r-DMP in a different location.

\begin{tabular}{lccc}
\hline Variables & Location I $(\mathbf{n = 1 7 4 )}$ & Location II $(\mathbf{n = 1 0 3})$ & Location III $(\mathbf{n = 9 0})$ \\
\hline BL & $167.64 \pm 5.01$ & $164.85 \pm 10.10$ & $167.30 \pm 5.07$ \\
FUH & $10.15 \pm 0.95^{\mathrm{a}}$ & $7.37 \pm 2.62^{\mathrm{b}}$ & $10.83 \pm 3.52^{\mathrm{a}}$ \\
RUH & $40.65 \pm 3.73$ & $37.35 \pm 2.56$ & $40.80 \pm 3.49$ \\
UC & $93.97 \pm 10.75^{\mathrm{a})}$ & $77.92 \pm 9.03^{\mathrm{b})}$ & $95.90 \pm 11.57^{\mathrm{a})}$ \\
r-DMP & $18.94 \pm 5.57^{\mathrm{a}}$ & $15.23 \pm 2.39^{\mathrm{b}}$ & $\left.19.27 \pm 6.58^{\mathrm{a}}\right)$ \\
e-DMP-BL & $17.14 \pm 0.55$ & $16.83 \pm 1.11$ & $17.10 \pm 0.56$ \\
e-DMP-FUH & $18.06 \pm 0.39^{\mathrm{a}}$ & $16.92 \pm 1.07^{\mathrm{b}}$ & $\left.18.34 \pm 1.44^{\mathrm{a}}\right)$ \\
e-DMP-RUH & $18.34 \pm 0.67$ & $17.74 \pm 0.46$ & $18.36 \pm 0.63$ \\
e-DMP-UC & $18.91 \pm 1.72^{\mathrm{a}}$ & $16.34 \pm 0.53^{\mathrm{b}}$ & $\left.19.21 \pm 1.85^{\mathrm{a}}\right)$ \\
\hline
\end{tabular}

$\mathrm{BL}=$ Body length, $\mathrm{FUH}=$ Front udder height, $\mathrm{RUH}=$ Rear udder height UC=Udder circumference, $r$-DMP $=$ Real day milk production, e-DMP-BL=Predicted daily milk production based on body length, e-DMP-UH=Predicted daily milk production based on UH, e-DMP-UC=Predicted daily milk production based on udder circumference. The location I: Jambuwer Village (the location of the study) II: Geger Village, District of Tulungagung, III: Precet Village, District of Malang. Superscripts a and $b$ in bold numbers were significantly different $(p<0.05)$ in the same row. Real daily milk production 


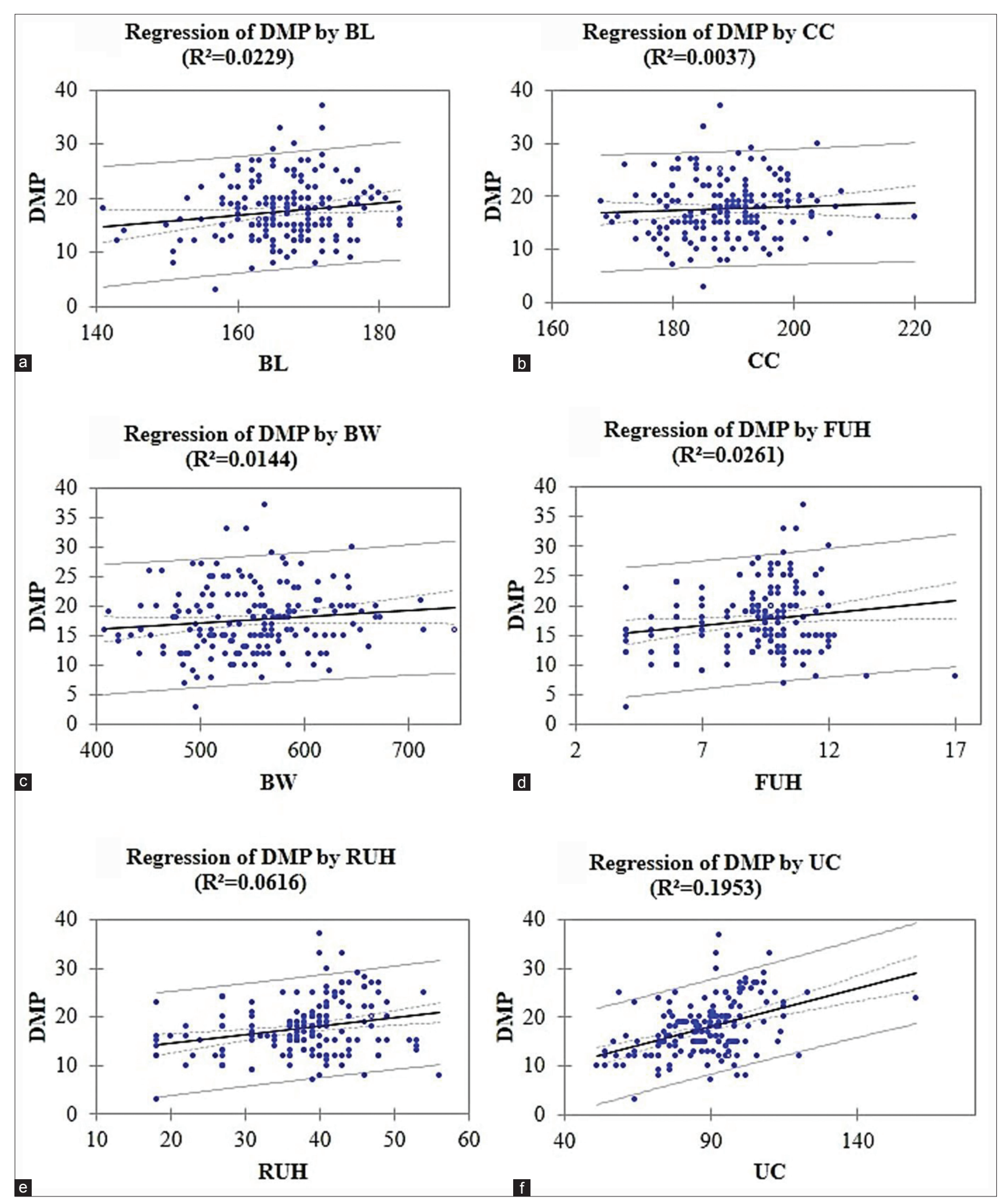

Figure-1: Regression equation of daily milk production (l/d) based on body length (a), chest circumference (b), bodyweight (c), front udder height (d), rear udder height (e), and udder circumference (f) in cm.

released by the anterior pituitary gland as a response to stimulation at milking and suction [21].

Furthermore, PRL is very important to maintain lactation [22,23]. IGF-1 affects the maintenance of the healthy histological structure and the functioning of the mammary gland [24,25], and it plays a key role in cellular glucose metabolism, amino acid uptake, glycogen synthesis, mitogenesis, and lipogenesis [26], thus affecting milk yield mediated by nutritional status, as well as stimulating synthesis and secretion of milk [27]. Anatomically bigger udders of dairy cows mean more parenchymal tissue, including a higher number of alveoli as the primary milk producers, thus needing much more endocrine support. In this study, the value of the 
correlation coefficients (r) for FUH, RUH, and UC was 0.16 (very weak), 0.25 (weak), and 0.44 (moderate), respectively. These variables affected $\mathrm{DMP}\left(\mathrm{R}^{2}\right)$ as $2.63 \%, 6.16 \%$, and $19.53 \%$, respectively, while the remaining percentages were influenced by the other variables. These results were similar to those from the study of Zebu cows in the northern region of Cameroon, in which there were significant correlations between the diameters and heights of udders and milk yield [28].

The e-DMP of the dairy cows through the equation of linear regression in this study matched the r-DMP of the cows and corresponded to the DMP of dairy cows that were owned by smallholders in other areas. Lower FUH and UC (in the location of study II: Geger Village, District of Tulungagung) was followed by lower r-DMP, e-DMP-FUH, and e-DMP-UC. In contrast, if the other predictors in all of the locations of the study were similar, this was followed by similar r-DMP and e-DMP.

\section{Conclusion}

The results from the present study indicate that DMP can be predicted using the body and udder morphometry based on the equations: $-1.30+0.11 * \mathrm{BL}$; $13.90+0.41 * \quad$ FUH; $11.02+0.18 * \mathrm{RUH} ; \quad$ and $3.87+0.16^{*} \mathrm{UC}$. The best equation for e-DMP was based on UC.

\section{Authors' Contributions}

SS conceived the idea and designed the mainframe of this manuscript under the supervision of IM and PS. SS, TIR, and SM coordinated the field data collection. SS performed the statistical analysis and drafted the manuscript. IM, PS, and WW critically read and revised the manuscript for its intellectual content. SU contributed in coordinating the collection of field data with TIR and SM. All of the authors read and approved the final manuscript.

\section{Acknowledgments}

This research was supported by funding from the Directorate General of Higher Education, Ministry of Research, Technology and Higher Education, Republic of Indonesia; Grant number: 122/SP2H/ PTNBH/DRPM/2019. The authors' thanks conveyed to Didik Isdiyanto, a veterinarian in Sendang, District of Tulungagung, and Nowo SiswoYuoro, a veterinarian in Wagir, District of Malang, Indonesia, who gave us access to farmers. The authors are also grateful to Yudhistira Eka Putra, Hanif Sabekti, Mirra Qurrotul Ilmi, Hanifah Muslimah Ananda, Melsa Netika, and Aghid Cahya Pisantra, who collected the data to depict the e-DMP against the r-DMP in other survey location areas. The authors are thankful to Tita Damayanti Lestari for the critical corrections of the manuscript.

\section{Competing Interests}

The authors declare that they have no competing interests.

\section{Publisher's Note}

Veterinary World remains neutral with regard to jurisdictional claims in published institutional affiliation.

\section{References}

1. Sutarno, S. and Setyawan, A.D. (2016) Review: The diversity of local cattle in Indonesia and the efforts to develop superior indigenous cattle breeds. Biodiversitas, 17(1): 275-295.

2. Hill, D.L. and Wall, E. (2017) Weather influences feed intake and feed efficiency in a temperate climate. J. Dairy Sci., 100(3): 2240-2257.

3. Sudono, A., Rosdiana, F. and Setiawan, B.S. (2003) Intensive Dairy Cattle Farming. Agromedia Pustaka, Jakarta. p33-34.

4. Rezaei, R., Wu, Z., Hou, Y., Bazer, F.W. and Wu, G. (2016) Amino acids and mammary gland development: Nutritional implications for milk production and neonatal growth. $J$. Anim. Sci. Biotech., 7(1): 20.

5. Pasaribu, A., Firmansyah F. and Idris, N. (2015) Analysis of factors affecting milk production in dairy cattle in Karo district, North Sumatra province. J. Indones. Anim. Sci., 18(1): 28-35.

6. Saputra, Y., Sudewo, A.T. and Utami, S. (2013) Relationship between chest circumference, body length, height, and location with the production of Sapera goat milk. Indones. Anim. Sci. J., 1(3): 1173-1182.

7. GPS. (2019) Global Positioning System. Available from: https://www.gps-latitude-longitude.com. Retrieved on 11-08-2019.

8. MCGA. (2019) Meteorological, Climatological, and Geophysical Agency. Available from: https://www.bmkg. go.id/?lang=EN. Retrieved on 11-08-2019.

9. Ni'am, H.U.M., Purnomoadi, A. and Dartosukarno, S. (2012) Relationship between body measurements and the bodyweight of female Bali cattle in various age groups. Anim. Agric. J., 1 (1): 541-556.

10. Rouaud, M. (2017) Probability, Statistics, and Estimation. Creative Commons Attribution-Non Commercial 4.0 International License (CC BY-NC 4.0), London. p58-68.

11. Sen, A. and Srivastava, M. (2011) Regression Analysistheory, Methods, and Applications. Springer-Verlag, Berlin. p64-66.

12. Durón-Benítez, A.A. and Huang, W.C. (2016) Using geometric morphometrics to quantify the variation of shape and magnitude of the pattern of milk production of dairy cattle. Open Access Lib. J., 3(9): e2928.

13. Sampurna, I.P., Saka, I.K., Oka, G.L. and Putra, S. (2014) Patterns of growth of Bali cattle body dimensions. ARPN J. Sci. Technol., 4(1): 20-30.

14. Cerqueira, J.O.L., Araújo, J.P.P, Vaz, P.S., Cantalapiedra, J., Blanco-Penedo, I. and Niza-Ribeiro, J.J.R. (2013) Relationship between zoometric measurements in HolsteinFriesian cow and cubicle size in dairy farms. Int. J. Morphol., 31(1): 55-63.

15. Duplessis, M., Girard, C.L., Santschi, D.E., Lefebvre, D.M. and Pellerin, D. (2014) Milk production and composition, and body measurements of dairy cows receiving intramuscular injections of folic acid and Vitamin B-12 in commercial dairy herds. Lives. Sci., 167(1): 186-194.

16. Ugur, F. (2005) Relationships between body measurement of dairy calves at six months of age and age at first calving and milk production. J. Central Eur. Agric., 6(2): 191-194.

17. Dijkstra, J., Forbes, J.M. and France, J. (2005) Quantitative Aspects of Ruminant Digestion and Metabolism. $2^{\text {nd }}$ ed. CABI Publishing, Wallingford. p7-9.

18. Petrovska, S. and Jonkus, M.R. (2014) Relationship between body condition score, milk productivity, and live weight of dairy cows. Res. Rural. Dev., 1 (1): 100-106. 
19. Błasiak, M. and Molik, E. (2015) Role of hormones and growth factors in initiating and maintaining the lactation of seasonal animals. Med. Weter., 71(8): 467-471.

20. Gross, J.J., Kessler, E.C., Bjerre-Harpoth, V., Dechow, C., Baumrucker, C.R. and Bruckmaier, R.M. (2014) Peripartal progesterone and prolactin have little effect on the rapid transport of immunoglobulin $\mathrm{G}$ into the colostrum of dairy cows. J. Dairy Sci., 97(5): 2923-293.

21. Mustofa, I., Utama, S., Restiadi, T.I., Mulyati, S. and Lestari, T.D. (2019) Animal Obstetrics. $1^{\text {st }}$ ed. Airlangga University Press, Surabaya. p60-64.

22. Mohanty, I., Senapati, M.R., Jena, D. and Behera, P.C. (2014) Ethnoveterinary importance of herbal galactagogues-a review. Vet. World, 7(5): 325-330.

23. Ponchon, B., Zhao, X., Ollier, S. and Lacasse, P. (2017) Relationship between glucocorticoids and prolactin during mammary gland stimulation in dairy cows. J. Dairy Sci., 100(2): 1521-1534.
24. Ha, W.T., Jeong, H.Y., Lee, S.Y. and Song, H. (2016) Review effects of the insulin-like growth factor pathway on the regulation of mammary gland development. Dev. Reprod., 20(3): 179-185.

25. Hoeflich, A. and Meyer, Z. (2017) Functional analysis of the IGF-system in milk. Best Pract. Res. Clin. Endocrinol. Metab., 31(4): 409e418.

26. Sutariya, S., Sunkesula, V., Kumar, R. and Shah, K. (2018) Review: Milk and milk products, insulin-like growth factor-1 and cancer. ECNU, 13(11): 696-705.

27. Kul, E. and Erdem, H. (2018) Relationships between milk insulin-like growth factor-I (IGF-I) concentration and body condition score with reproductive performance and milk yield. Large Anim. Rev., 24(2): 65-70.

28. Mingoas, K.J., Awah-Ndukum, J., Dakyang, H. and Zoli, P.A. (2017) Effects of body conformation and udder morphology on milk yield of zebu cows in North region of Cameroon, Vet. World, 10(8): 901-905.

$* * * * * * * *$ 